ISSN: 2536-5339

\title{
Aile Gelir Düzeyinin 8-14 Yaş Arası Bireylerde Vücut Kompozisyonuna Etkisi
}

\author{
Saadet ÖZTÜTÜNCÜ ${ }^{1}$ \\ Mustafa ÖZDAL ${ }^{1}$ \\ ${ }^{1}$ Gaziantep Üniversitesi, Beden Eğitimi ve Spor Yüksekokulu, GAZIANTEP
}

Mehmet VURAL ${ }^{1}$

Künye: Öztütüncü, S., Özdal, M. ve Vural, M. (2018). Aile Gelir Düzeyinin 8-14 Yaş Arası Bireylerde Vücut Kompozisyonuna Etkisi. Gaziantep Üniversitesi Spor Bilimleri Dergisi, 3(3): 48-58.

\begin{abstract}
Öz
Çalışmamızın amacı, Gaziantep ilinde yaşayan 8-14 yaş arasındaki bireylerde aile gelir durumunun vücut kompozisyonunu etkisini incelemektir. Çalışmamıza Gaziantep ilinde 8-14 yaş arasında toplamda 2463 erkek $(n=1320)$ ve bayan $(n=1143)$ birey gönüllü olarak katıldı. Denekler 3 ayrı gelir düzeyi kategorisine (Düşük=1500TL ve altı, $n=1029$; Orta=1501-3000TL, $n=807$; Yüksek=3001TL ve üzeri, $n=627$ ) ayrılarak boy ve kiloları ölçüldü. Elde edilen verilerin analizi için bağımsız gruplarda $T$ testi, tek yönlü varyans analizi ve LSD testleri kullanıldı. Bayan bireylerin erkek bireylere göre boy uzunluklarının daha yüksek olduğu tespit edildi. Gelir düzeyi yüksek olan grubun gelir düzeyi orta ve düşük olan gruplara göre boy uzunluğu, vücut ağırlığı ve beden kitle indeksi özelliklerinde anlamlı farklılık görüldü $(p<0.05)$. Erkek ve bayan bireyler gelir düzeylerine göre gruplandığında vücut kompozisyonu özelliklerinde anlamlı farklılık görülmedi $(p>0.05)$. Gelir düzeyine göre erkek ve bayan bireyler ayrı ayrı incelendiğinde ise erkek bireylerde de bayan bireylerde de boy uzunluğunda ve vücut ağırlığında gelir düzeyi yüksek olan grup ile orta ve düşük olan grup ile farklılık; beden kitle indeksinde ise gelir düzeyi yüksek olan grup ile orta ve düşük olan grup ile anlamlı farklılık ve gelir düzeyi orta olan grup ile düşük olan grup arasında anlamlı farklılık saptandı $(p<0.05)$. Sonuç olarak, aile gelir düzeyinin 8-14 yaş arasındaki bireylerin boy uzunluğunu, vücut ağırığını ve beden kitle indeksini arttırdığı söylenebilir.
\end{abstract}

Anahtar Kelimeler: Gelir düzeyi, Boy uzunluğu, Vücut ağırlığı, Beden kitle indeksi, Cocuk

\section{Orijinal Makale}

Yayın Bilgileri

Gönderi Tarihi: 11.07 .2018

Kabul Tarihi: 04.09.2018

Yayın Tarihi: 24.09.2018

Sorumlu Yazar

e-mail: mehmetvrl27@hotmail.com

DOI: 10.31680 /gaunjss.442503

\section{Effect of Income Level on Body Composition of 8-14 Aged Individuals}

\begin{abstract}
The purpose of the study was to examine the effect of income level on body composition in the aged 8-14 age group in Gaziantep province. Male $(n=1320)$ and female $(n=1143)$ individuals $(N=2463)$ between the ages of 8-14 participated in the study voluntarily. The subject's height and weight were measured by divided into 3 different income level categories (Low $=1500 T L$ and below, $n=1029$, Medium $=$ 1501-3000TL, $n=807$, High = 3001TL and over, $n=627$ ). Independent $T$ test, oneway analysis of variance and LSD tests were used for the analysis of the obtained data. Female individuals were found to have higher height lengths than males $(p<0.05)$. There was a significant difference in height, body weight and body mass index according to income level middle and low group $(p<0.05)$. When male and female individuals were grouped in terms of their income levels, there was no significant difference in body composition characteristics $(p>0.05)$. When the male and female individuals were examined separately according to income level, the difference was found between high income level and middle and low income groups in body weight and height in both group. A significant difference was found in the body mass index between the group with high income level and the middle and a significant difference was found between the group with low income and the group with middle income $(p<0.05)$. As a result, it can be said that the income level increased the height, body weight and body mass index of the 8-14 year olds.
\end{abstract}

Key Words: Income level, Height, Body weight, Body mass index, Child

\section{Original Article}

Article Info

Received: 11.07 .2018

Accepted: 04.09.2018

Published: 24.09.2018

\section{Corresponding Author}

e-mail: mehmetvrl27@hotmail.com 


\section{Giriş}

Obezite ve şişmanlık yaşam boyunca birçok insanın önemli sağlık problemlerinden biridir (Öztürk, 2005). Çocukluk, ergenlik ve yetişkinlik dönemlerinde obezite birçok hastalığın sebebi olmuştur (Boreham ve ark., 2004). Düzensiz beslenme, düşük düzeyde fiziksel aktivite obezite riskini artırır. Obezite, çok yaygın bir beslenme bozukluğu olup metabolizma ve kalp-damar hastalıkları için glikoz (intoleransı), kan lipid düzeyi bozukluğu (dislipidemi), kan insilün düzeyinin yüksek olması (hiperinsülimeni), insülin direnci, hipertansiyon ve damar sertliği (ateroskleroz) da dahil olmak üzere ilgili sağlık sorunları ile ilişkilidir. Vücut yağ kütlesinin, yağsız vücut kütlesine oranla artması ile özellikle, yağ dokunun organ boşluğunda ağırlıklı olarak artması metabolik sendromu ve kardiyovasküler hastalığın gelişiminde önemli bir rol oynar. Ayrıca vücut kompozisyonundaki hızlı kilo değişikliği ve aşırı kilo kaybı ile birlikte yeme bozukluğu ve ciddi sağlık problemlerine yol açabilir. Gıda alımının kısıtlanması besin eksikliği ve düşük yağ oranına sebep olur (Müller, 2009). Çok az vücut yağlıığı da sağlık sorunlarına yol açmaktadır. Çünkü vücudun normal fizyolojik fonksiyonlarını devam ettirebilmesi için bir miktar yağa intiyaç vardır. Fosfolipid gibi bazı esansiyel yağlara hücre zarının yapısında ihtiyaç varken, trigliseridler gibi adipose dokuda bulunan esansiyel olmayan yağlara depo metabolik yakıtlar olarak ihtiyaç vardır (Heyward ve ark., 1996).

Obeziteyi etkileyen faktörlere ek olarak ailenin sosyoekonomik durumu da obezite etiyolojisinde önemli bir faktördür. Sosyoekonomik düzeyi yüksek olan ailelerin çocukları aşırı beslenme nedeniyle şişmanlarken, sosyoekonomik düzeyi düşük ve kalabalık ailelerin çocukları dengesiz beslenmeye bağlı olarak şişmanlamaktadır. Dengeli beslenme alışkanlığı kazanmamış, özellikle okul çağındaki çocuklar ve gençlerin yağ ve şeker içeriği yüksek, fast-food tarzı gıdalarla beslenme eğilimleri daha fazladır (Murasko, 2011).

Bu bilgiler ışığında çalışmamızın amacı 8-14 yaş arasındaki bireylerde aile gelir durumunun vücut kompozisyonunu etkisini incelemektir.

\section{Yöntem}

\section{Katılımcılar}

Çalışmamıza Gaziantep ilinde yaşayan 8-14 yaş arasında toplamda 2463 erkek $(n=1320)$ ve bayan $(n=1143)$ birey gönüllü olarak katıldı. Denekler 3 ayrı gelir düzeyi kategorisine (Düşük=1500TL ve altı, n=1029; Orta=1501- 3000TL, n=807; 
Yüksek=3001TL ve üzeri, $n=627$ ) ayrılarak boy ve kiloları ölçüldü. Çalışma için veli onam formu her birey için alınmıştır.

\section{Ölçüm Protokolleri}

\section{Boy, Vücut Ağırlığı Ölçümü ve Beden Kitle İndeksinin Hesaplanması}

Öğrencilerin vücut ağırlıkları yüksek hassasiyetli baskül terazi üzerinde çıplak ayak ve minimum elbise bulundurularak kg cinsinden ölçülmüştür (SECA, Almanya). Boyları ise hassaslık durumu $0.01 \mathrm{~m}$ olan (SECA, Almanya) stadiometre ile ölçme tekniğiyle alınmıştır. Öğrencilerin Beden Kitle İndeksleri, vücut ağırlıklarının boy ölçümlerinin karesine oranı formülüyle hesaplanmıştır (Lohman ve ark., 1988).

\section{Verilerin Analizi}

8-14 yaş arasında toplamda 2463 erkek $(n=1320)$ ve bayan $(n=1143)$ birey gönüllü denek olarak katıldı. Denekler 3 ayrı gelir düzeyi kategorisine (Düşük=1500TL ve altı, n=1029; Orta=1501- 3000TL, n=807; Yüksek=3001TL ve üzeri, $n=627$ ) ayrılarak boy ve kiloları ölçüldü. Elde edilen verilerin analizi için bağımsız gruplarda T testi, tek yönlü varyans analizi ve LSD testleri kullanıldı.

\section{Bulgular}

Tablo 1. Araştırma grubunun tanımlayıcı özellikleri

\begin{tabular}{lccccc}
\hline & $\mathrm{N}$ & Minimum & Maksimum & Ortalama & Std. Sapma \\
\hline Yaş (yıl) & & 8,00 & 14,00 & 11,21 & 0,79 \\
Boy uzunluğu (cm) & & 114,00 & 170,00 & 143,43 & 7,74 \\
Vücut ağırlı̆̆ı (kg) & 2463 & 19,10 & 95,50 & 39,36 & 10,26 \\
BKI (kg/m²) & & 11,18 & 39,54 & 18,92 & 3,66 \\
\hline Tablo 1 'de
\end{tabular}

Tablo 1'de katılımcıların tanımlayıcı özellikleri verilmiştir. Bireylerin yaş ortalaması $11.21 \pm 0.79$ yıl, boy uzunlukları $143.00 \pm 4.74$, vücut ağırlığı $39.36 \pm 10.26$ ve beden kitle indeksi $18.92 \pm 3.66$ olarak ölçülmüştür.

Tablo 2. Cinsiyet değişkeni açısından ölçülen özelliklerin analizi

\begin{tabular}{llccccc}
\hline & & $\mathrm{N}$ & Ortalama & Std. Sapma & $\mathrm{t}$ & $\mathrm{p}$ \\
\hline Boy uzunluğu & Erkek & 1320 & 143,10 & 7,41 & & $\mathbf{0}$ \\
(cm) & Kız & 1143 & 143,81 & 8,09 & & $\mathbf{0 , 0 2 4}$ \\
Vücut ağırlığı & Erkek & 1320 & 39,23 & 10,35 & & \\
$(\mathrm{~kg})$ & Kız & 1143 & 39,50 & 10,16 & $-0,646$ & 0,518 \\
BKI $\left(\mathrm{kg} / \mathrm{m}^{2}\right)$ & Erkek & 1320 & 18,96 & 3,73 & & \\
& Kız & 1143 & 18,89 & 3,58 & 0,461 & 0,645 \\
\hline
\end{tabular}


Tablo 2'de (şekil 1) katııımcıların cinsiyet değişkeni açısından ölçülen özelliklerinin analizi verilmiştir. Katıımcıların boy uzunluğu ile cinsiyet özellikleri karşılaştırıldığında bayan katıımcıların boy ortalamaları ile erkekler arasında anlamlı bir farklılı̆ın olduğu tespit edilirken $(p<0,05)$, diğer parametrelerde herhangi bir anlamlı farklıığa rastlanılmamıştır $(p>0,05)$.

Şekil 1. Cinsiyet değişkeni açısından ölçülen özellikler

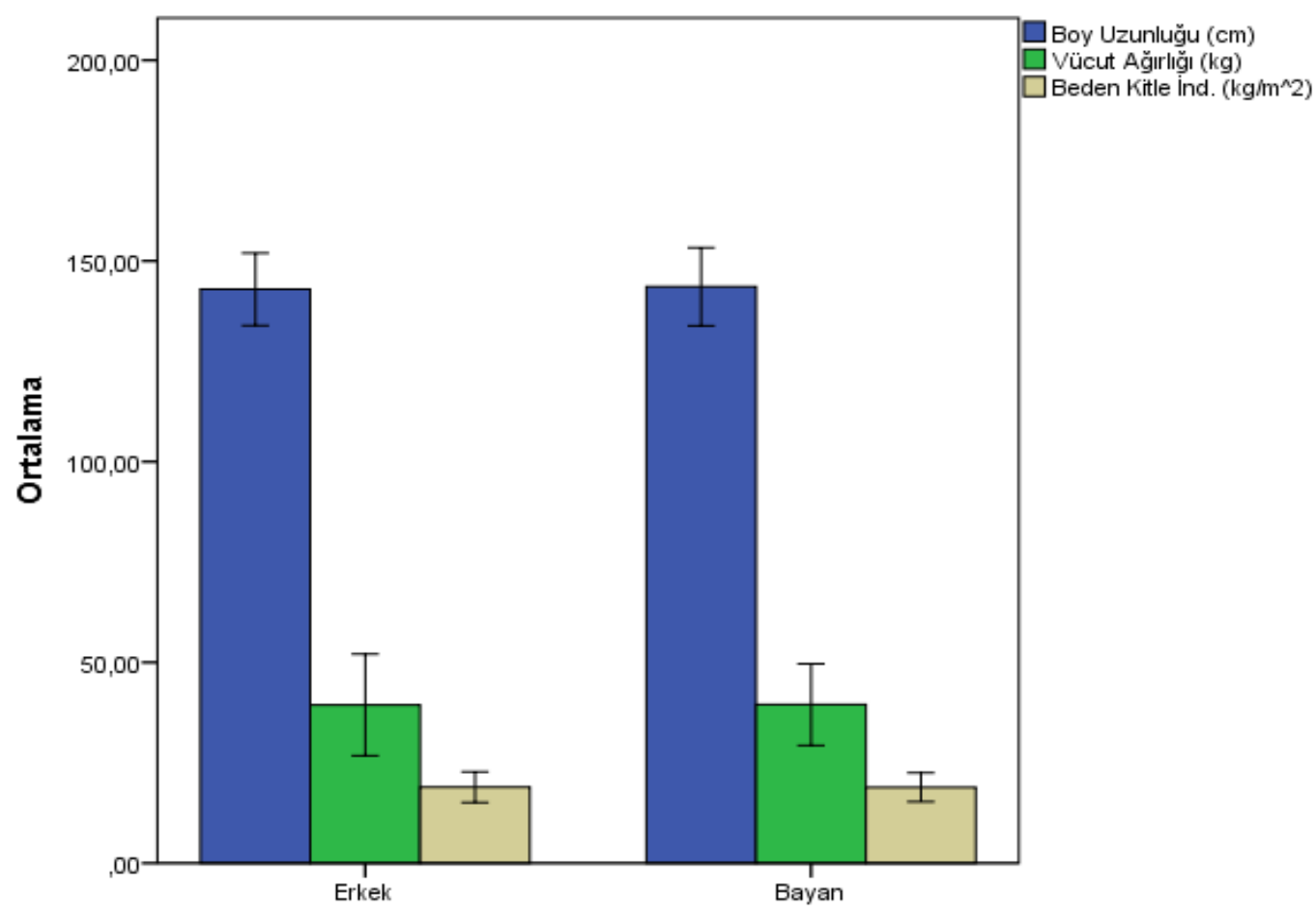

Tablo 3. Gelir düzeyi değişkeni açısından ölçülen özelliklerin analizi

\begin{tabular}{|c|c|c|c|c|c|c|}
\hline & & $\mathrm{N}$ & Ortalama & Std. Sapma & $f$ & $\mathrm{p}$ \\
\hline \multirow{3}{*}{$\begin{array}{l}\text { Boy } \\
\text { uzunluğu } \\
\text { (cm) }\end{array}$} & Düşük & 1029 & 142,70 & 7,50 & \multirow{3}{*}{37,097} & \multirow{3}{*}{0,001} \\
\hline & Orta & 807 & 142,59 & 7,42 & & \\
\hline & Yüksek $^{\mathrm{a} b}$ & 627 & 145,69 & 8,09 & & \\
\hline \multirow{3}{*}{$\begin{array}{l}\text { Vücut ağırlığı } \\
\text { (kg) }\end{array}$} & Düşük & 1029 & 37,79 & 9,54 & \multirow{3}{*}{49,242} & \multirow{3}{*}{0,001} \\
\hline & Orta $^{a}$ & 807 & 38,72 & 9,54 & & \\
\hline & Yüksek $^{\text {ab }}$ & 627 & 42,73 & 11,47 & & \\
\hline \multirow{3}{*}{ VKi $\left(\mathrm{kg} / \mathrm{m}^{2}\right)$} & Düşük & 1029 & 18,37 & 3,44 & \multirow{3}{*}{35,689} & \multirow{3}{*}{0,001} \\
\hline & Orta $^{a}$ & 807 & 18,85 & 3,41 & & \\
\hline & Yüksek $^{\text {a b }}$ & 627 & 19,92 & 4,10 & & \\
\hline
\end{tabular}

a Gelir düzeyi düşük olan grup ile anlamlı farklılık

${ }^{\text {b }}$ Gelir düzeyi orta olan grup ile anlamlı farklılık

Tablo 3 (Şekil 2) incelendiğinde, elde ettiğimiz verilere göre okulların varsayılan sosyoekonomik düzeyleri azaldıkça düşük kiloluluk oranlarının anlamlı olarak artma 
eğiliminde olduğu saptanmıştır. Yaptığımız çalışmamızda sosyoekonomik seviyenin yükselmesiyle doğru orantılı olarak fazla kiloluluk ve VKİ oranlarının da belirgin artma eğilimi göstermesi, gelişmekte olan ülkelerdeki görünümle uyuşmaktadır.

Şekil 2. Gelir düzeyi değişkeni açısından ölçülen özellikler

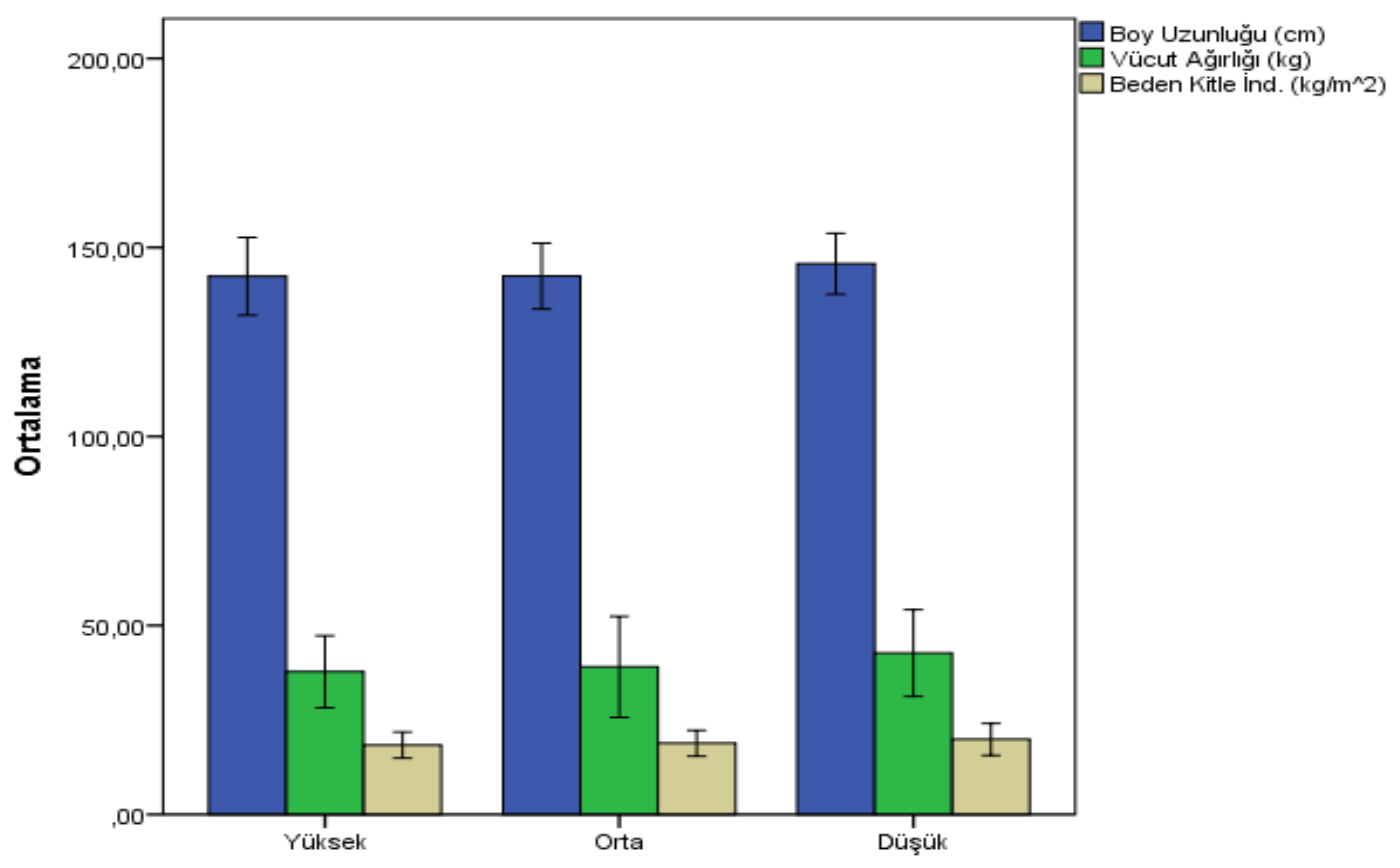

Tablo 4. Gelir düzeylerine göre ayrıldığında cinsiyet değişkeni açısından ölçülen özelliklerin analizi

\begin{tabular}{|c|c|c|c|c|c|c|c|}
\hline & & & $N$ & $\begin{array}{c}\text { Ortalam } \\
\mathrm{a}\end{array}$ & $\begin{array}{c}\text { Std. } \\
\text { Sapma }\end{array}$ & $\mathrm{t}$ & $p$ \\
\hline \multirow{5}{*}{$\begin{array}{l}\text { Düşük } \\
\text { Gelir } \\
\text { Düzeyi }\end{array}$} & Boy uzunluğu & Erkek & 527 & 142,28 & 6,99 & \multirow{2}{*}{$-1,820$} & \multirow{2}{*}{0,069} \\
\hline & $(\mathrm{cm})$ & $\mathrm{K} \mathrm{Iz}$ & 502 & 143,14 & 7,98 & & \\
\hline & Vücut ağırlığı & Erkek & 527 & 37,46 & 9,60 & \multirow{2}{*}{$-1,151$} & \multirow{2}{*}{0,250} \\
\hline & $(\mathrm{kg})$ & KIz & 502 & 38,14 & 9,48 & & \\
\hline & $\mathrm{BKI}\left(\mathrm{kg} / \mathrm{m}^{2}\right)$ & Erkek & $\begin{array}{l}527 \\
50 ?\end{array}$ & 18,33 & $\begin{array}{l}3,53 \\
3,35\end{array}$ & $-0,450$ & 0,653 \\
\hline \multirow{5}{*}{$\begin{array}{c}\text { Orta } \\
\text { Gelir } \\
\text { Düzeyi }\end{array}$} & Boy uzunluğu & Erkek & 446 & $\begin{array}{l}10,42 \\
142,36\end{array}$ & $\begin{array}{l}6,85 \\
6,85\end{array}$ & \multirow{2}{*}{$-0,968$} & \multirow{2}{*}{0,325} \\
\hline & $(\mathrm{cm})$ & Kız & 361 & 142,88 & 8,07 & & \\
\hline & Vücut ağırlığı & Erkek & 446 & 38,46 & 9,13 & \multirow{2}{*}{$-0,881$} & \multirow{2}{*}{0,375} \\
\hline & $(\mathrm{kg})$ & $\mathrm{K} \mathrm{Iz}$ & 361 & 39,06 & 10,04 & & \\
\hline & BKI $\left(\mathrm{kg} / \mathrm{m}^{2}\right)$ & Erkek & 446 & 18,81 & 3,35 & $-0,391$ & \multirow{2}{*}{0,696} \\
\hline \multirow{6}{*}{$\begin{array}{l}\text { Yüksek } \\
\text { Gelir } \\
\text { Düzeyi }\end{array}$} & Boy uzunluğu & $\begin{array}{l}\text { Kiz } \\
\text { Erkek }\end{array}$ & $\begin{array}{l}361 \\
347\end{array}$ & $\begin{array}{c}18,91 \\
145,28\end{array}$ & $\begin{array}{l}3,49 \\
8,25\end{array}$ & \multirow{2}{*}{$-1,423$} & \\
\hline & $(\mathrm{cm})$ & $\mathrm{K} \mathrm{Iz}$ & 280 & 146,20 & 7,88 & & 0,155 \\
\hline & Vücut ağırlığı & Erkek & 347 & 42,92 & 11,92 & \multirow[b]{2}{*}{0,456} & \multirow[b]{2}{*}{0,648} \\
\hline & $(\mathrm{kg})$ & $\mathrm{K} \mathrm{Iz}$ & 280 & 42,50 & 10,91 & & \\
\hline & vki/kaln ln & Erkek & 347 & 20,10 & 4,22 & \multirow{2}{*}{1,219} & \multirow{2}{*}{0,223} \\
\hline & $V k I(\mathrm{~kg} / \mathrm{m})$ & $\mathrm{K} ı \mathrm{z}$ & 280 & 19,69 & 3,93 & & \\
\hline
\end{tabular}

Tablo 4' de (Şekil 3) katııımcıların gelir düzeylerine göre ayrıldığında cinsiyet değişkeni açısından ölçülen özelliklerini analizi verilmiştir. Analize göre ölçülen 
özelliklerde ve cinsiyet bazında gelir düzeyine göre herhangi bir anlamlı farklılık ortaya çıkmamıştır ( $p>0.05)$.

Şekil 3. Gelir düzeyi düşük bireylerin cinsiyet değişkeni açısından ölçülen özellikleri

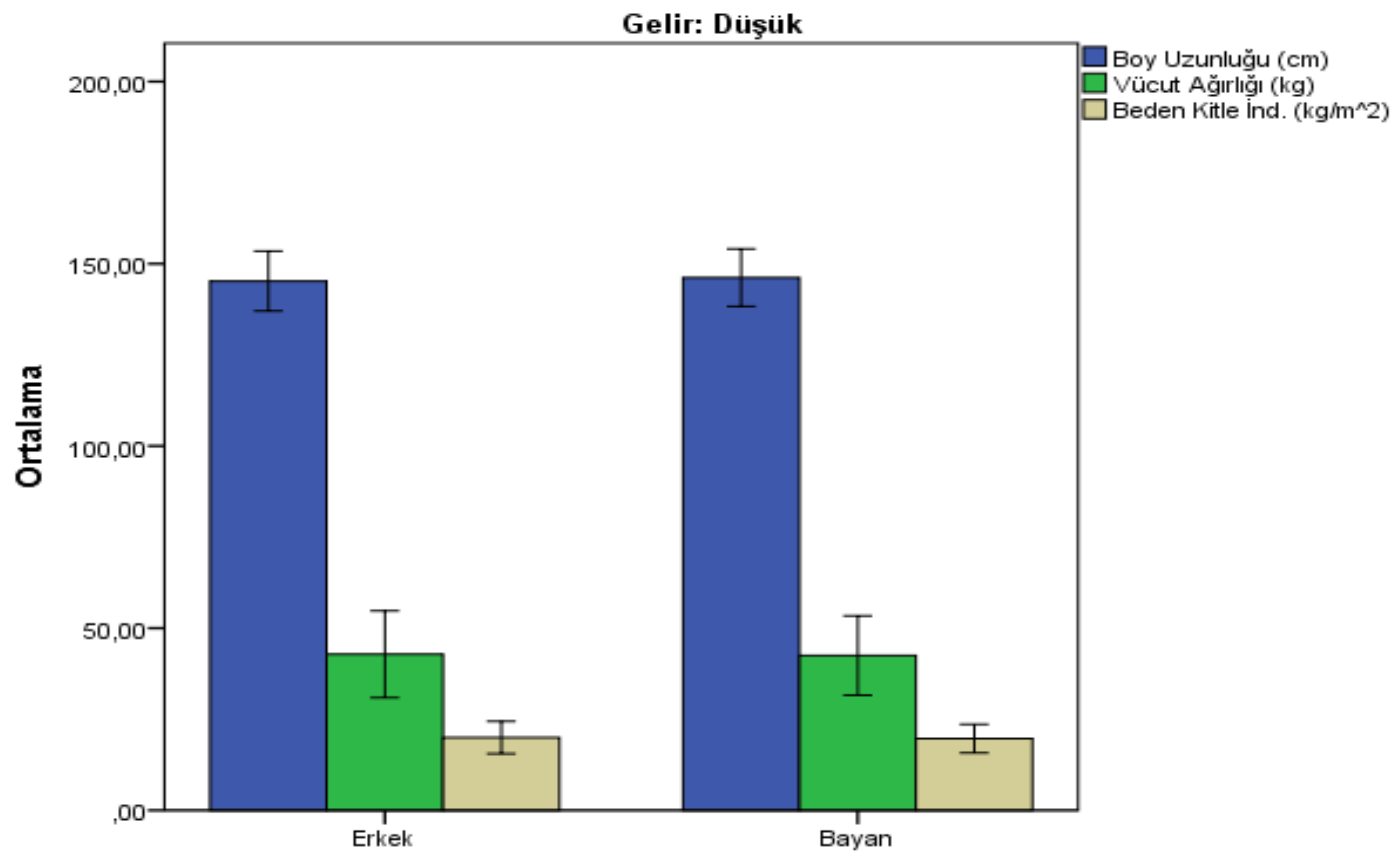

Tablo 5. Cinsiyete göre ayrıldığında gelir düzeyi değişkeni açısından ölçülen özelliklerin analizi

\begin{tabular}{|c|c|c|c|c|c|c|c|}
\hline & & & $\mathrm{N}$ & Ortalama & Std. Sapma & $f$ & $p$ \\
\hline \multirow{9}{*}{ Erkek } & \multirow{4}{*}{$\begin{array}{c}\text { Boy } \\
\text { uzunluğu } \\
(\mathrm{cm})\end{array}$} & Düşük & 527 & 142,28 & 6,99 & \multirow{4}{*}{21,039} & \multirow{4}{*}{0,001} \\
\hline & & Orta & 446 & 142,36 & 6,85 & & \\
\hline & & Yüksek $^{\text {a b }}$ & 347 & 145,28 & 8,25 & & \\
\hline & & Düşük & 527 & 37,46 & 9,60 & & \\
\hline & \multirow{3}{*}{$\begin{array}{l}\text { Vücut ağırlığı } \\
(\mathrm{kg})\end{array}$} & Orta & 446 & 38,46 & 9,13 & \multirow[t]{3}{*}{32,493} & \multirow[t]{3}{*}{0,001} \\
\hline & & Yüksek $^{\mathrm{a} b}$ & 347 & 42,92 & 11,92 & & \\
\hline & & Düşük & 527 & 18,33 & 3,53 & & \\
\hline & \multirow[t]{2}{*}{ BKI $\left(\mathrm{kg} / \mathrm{m}^{2}\right)$} & Orta $^{a}$ & 446 & 18,81 & 3,35 & \multirow[t]{2}{*}{24,809} & \multirow[t]{2}{*}{0,001} \\
\hline & & Yüksek $^{\mathrm{ab}}$ & 347 & 20,09 & 4,22 & & \\
\hline \multirow{9}{*}{$\mathrm{K} ı \mathrm{Z}$} & \multirow{3}{*}{$\begin{array}{c}\text { Boy } \\
\text { uzunluğu } \\
(\mathrm{cm})\end{array}$} & Düşük & 502 & 143,14 & 7,98 & \multirow{3}{*}{16,804} & \multirow{3}{*}{0,001} \\
\hline & & Orta & 361 & 142,88 & 8,07 & & \\
\hline & & Yüksek $^{\text {a b }}$ & 280 & 146,20 & 7,88 & & \\
\hline & \multirow{4}{*}{$\begin{array}{l}\text { Vücut ağırlığı } \\
(\mathrm{kg})\end{array}$} & Düşük & 502 & 38,14 & 9,48 & \multirow{4}{*}{17,496} & \multirow{3}{*}{0,001} \\
\hline & & Orta & 361 & 39,06 & 10,04 & & \\
\hline & & Yüksek $^{\mathrm{a} b}$ & 280 & 42,50 & 10,91 & & \\
\hline & & Düşük & 502 & 18,42 & 3,35 & & \\
\hline & \multirow[t]{2}{*}{$\mathrm{VKI}\left(\mathrm{kg} / \mathrm{m}^{2}\right)$} & Orta $^{a}$ & 361 & 18,91 & 3,49 & \multirow[t]{2}{*}{11,518} & \multirow[t]{2}{*}{0,001} \\
\hline & & Yüksek $^{\text {a b }}$ & 280 & 19,69 & 3,93 & & \\
\hline
\end{tabular}

${ }^{a}$ Gelir düzeyi düşük olan grup ile anlamlı farklılık

${ }^{\text {b }}$ Gelir düzeyi orta olan grup ile anlamlı farklılık 
Tablo 5' de (şekil 4,5) katılımcıların cinsiyete göre ayrıldığında gelir düzeyi değişkeni açısından ölçülen özelliklerinin analizi verilmiştir. Tablo 5 incelendiğinde erkek katılımcıların boy uzunluğu parametresinde gelir düzeyi yüksek olan grubun gelir düzeyi düşük ve orta olan grup ile vücut ağırlığı parametresinde gelir düzeyi yüksek olan grubun gelir düzeyi düşük ve orta olan grup ile VKI parametresinde ise gelir düzeyi orta olan grubun gelir düzeyi düşük olan grup ile ve gelir düzeyi yükse olan grubun ise gelir düzeyi orta ve düşük olan grup arasında anlamlı bir farklılık ortaya çıkmışıı. Bayan katıımcıların boy uzunluğu parametresinde gelir düzeyi yüksek olan grubun gelir düzeyi düşük ve orta olan grup ile vücut ağırlığı parametresinde gelir düzeyi yüksek olan grubun gelir düzeyi düşük ve orta olan grup ile VKi parametresinde ise gelir düzeyi orta olan grubun gelir düzeyi düşük olan grup ile ve gelir düzeyi yükse olan grubun ise gelir düzeyi orta ve düşük olan grup arasında anlamlı bir farklılık ortaya çıkmıştır.

Şekil 4. Erkek bireylerin gelir düzeyi değişkeni açısından ölçülen özellikleri

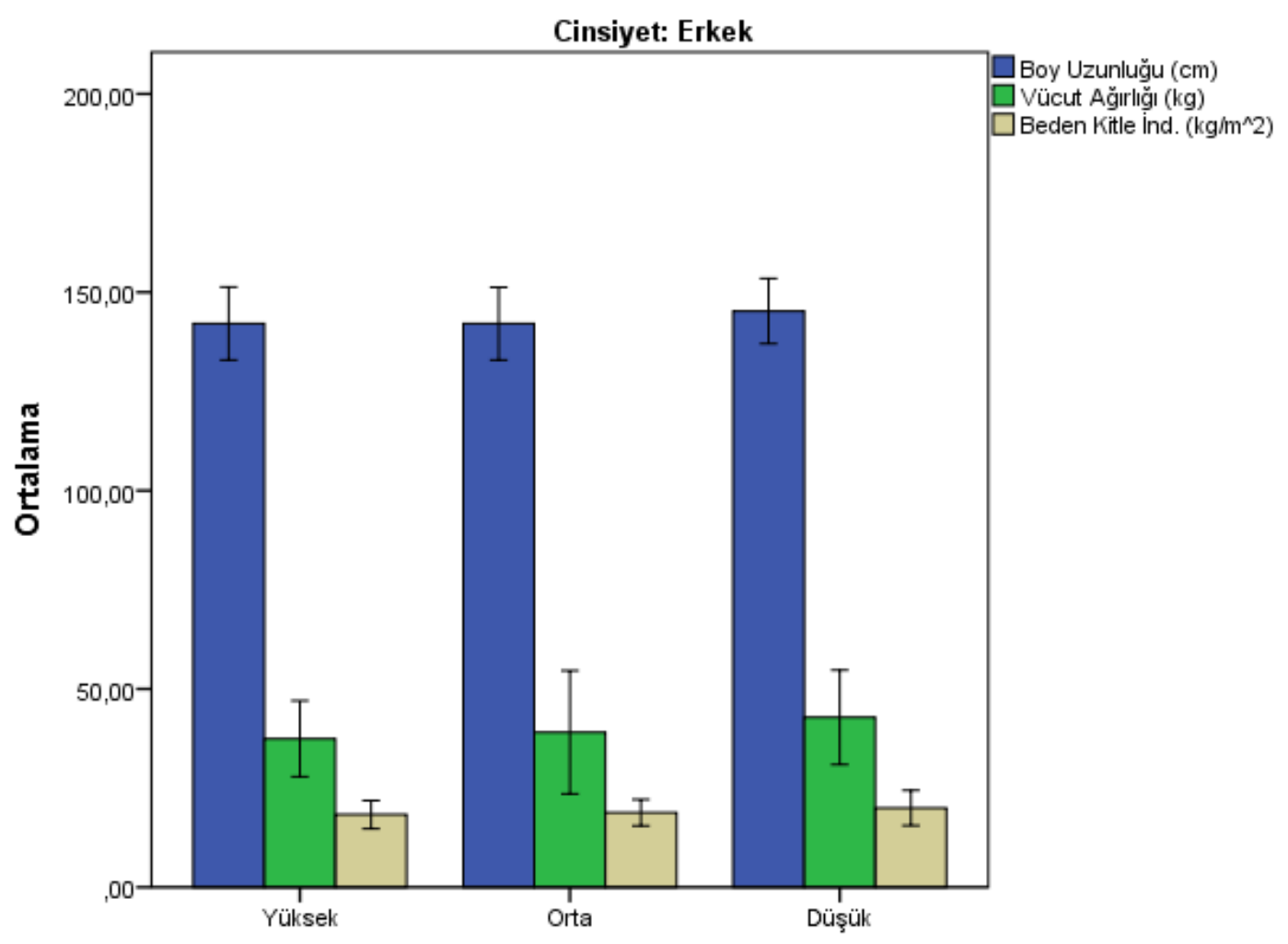


Şekil 5. Bayan bireylerin gelir düzeyi değişkeni açısından ölçülen özellikleri

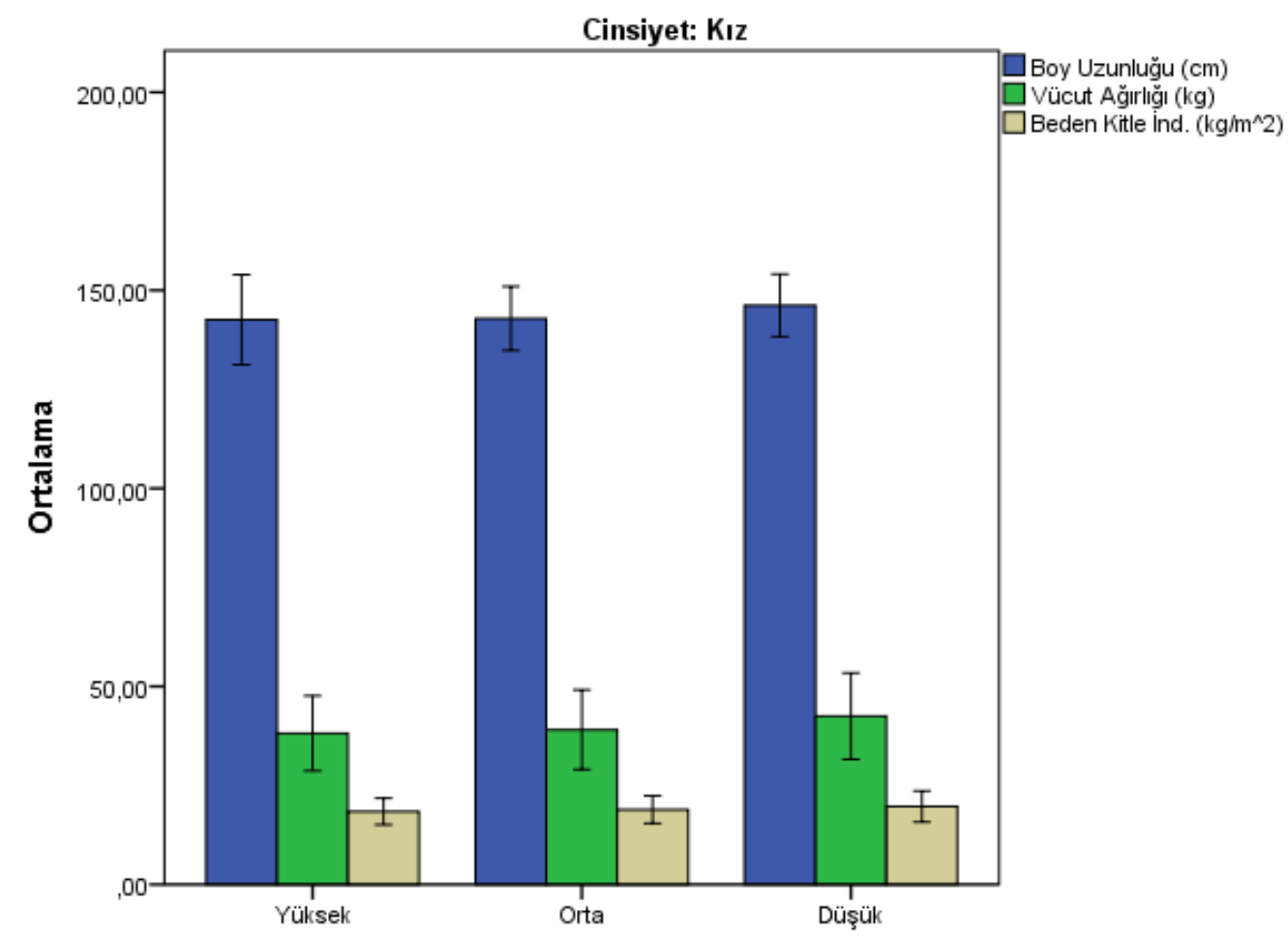

\section{Tartışma ve Sonuç}

Çalışmamızın amacı, Gaziantep ilinde yaşayan 8-14 yaş arasındaki bireylerde aile gelir durumunun vücut kompozisyonunu oluşturan vücut ağırığı, boy uzunluğu ve beden kitle indeksine etkisini incelemektir. Çalışmamıza Gaziantep ilinde yaşayan 814 yaş arasında toplamda 2463 erkek $(n=1320)$ ve bayan $(n=1143)$ birey gönüllü denek olarak katıldı. Denekler 3 ayrı gelir düzeyi kategorisine ayrılarak boy ve kiloları ölçüldü. Sonuç olarak, aile gelir düzeyinin 8-14 yaş arasındaki bireylerin boy uzunluğunu, vücut ağırı̆ğını ve beden kitle indeksini arttırdığı söylenebilir.

Obezite sıklığı sosyoekonomik düzeye göre değişim göstermektedir. Gelişmiş ülkelerde düşük sosyoekonomik düzeydeki ailelerde ve çocuklarında obezite sık iken gelişmekte olan ülkelerde ekonomik düzeyi yüksek olan ailelerde daha fazladır (Chen ve ark., 2011). Ülkemizde obezite prevalansı daha çok yüksek ve orta sosyoekonomik düzeydeki bireylerde görülmektedir (Glasper, 2010). Bizim çalışmamızda aile gelir düzeyinin 8-14 yaş arasındaki bireylerin boy uzunluğunu, vücut ağırlığını ve beden kitle indeksini arttırdığı söylenebilir.

1999 yılında 4260 okul çocuğu üzerinde yapılan bir çalışmada obezite prevalansı \%6.3 saptanmıştır. Bu çalışmaya göre ailenin sosyokültürel ve sosyoekonomik düzeyi ile obezite arasında istatistiksel olarak anlamlı ilişki saptanmıştır (Tüzün, 1999). Çalışmamızda VKi saptanan olguların çoğunluğunun 
sosyoekonomik düzeyi daha yüksek olan grubu temsil eden okulda gözlemlenmesi bu saptamayla uyumludur. Sosyoekonomik düzeyi düşük gruplarda da beslenme olanaklarının sınırlı olması ve dolayısıyla bireylerin tek yönlü beslenmeleri nedeniyle obezite önemli oranda görülebilmektedir (Süzek ve ark., 2005). Sosyoekonomik düzey ile obezite arasındaki ilişkinin temelinde yeme alışkanlığı ve fiziksel aktivite düzeyi yatmaktadır. Düşük sosyoekonomik düzeydeki ailelerin çocuklarının spor ve diğer fiziksel aktiviteler için daha az fırsatları olduğu saptanmıştır (Drewnowsnki ve ark., 2004).

Ankara'da 2000 yılında yapılan başka bir çalışmada erkek çocuklarda ve yüksek sosyoekonomik düzey okullarda okuyan çocuklarda obezite sıklığının daha fazla olduğu belirtilmektedir (Toyran, 2006). Ülkemizde ilköğretim öğrencilerinde obezite gelişimini etkileyen risk faktörlerinin araştırıldığı bir çalışmada obez olan grupta ekonomik durumu iyi olan ailelerin çoğunlukta olduğu saptanmıştır (Uskun ve ark., 2005). Muğla'da aile gelirinin çocukluk çağı obezitesi ile ilişkili olduğu, Ankara'da gelir seviyesi yüksek olan ailelerin çocuklarında obezite sıklı̆ının daha yüksek olduğu saptanmıştır (Akgün ve ark., 2006, Özdemir ve ark., 2005).

Yaptığımız çalışmada sosyoekonomik seviyenin yükselmesiyle doğru orantılı olarak fazla kiloluluk ve VKi oranlarının da belirgin artma eğilimi göstermesi, gelişmekte olan ülkelerdeki görünümle uyuşmaktadır. Ailenin ekonomik olanakları çocuğun beslenme durumunun en güçlü belirleyicilerinden biridir. Çalışmamızda sosyoekonomik düzeyi yüksek ailelerin çocuklarında daha sık obezite görülmesinin nedenleri olarak, çocukların yüksek gelir düzeyi ile doğru orantılı olarak ulaşabildiği besin tüketim maddelerinin çokluğunun ve çeşitliğinin artması, fastfood tarzı beslenme ve obesojenik besinlere ulaşım kolaylığı ve sedanter davranışların artışı düşünülebilir. Bunların sonucunda da çocukların günlük enerji gereksinimlerinin üzerinde kalori alımı ve bunun yeterli fiziksel aktiviteyle dengelenmemesinin çocuklarda fazla kiloluluk ve obeziteye yol açtığı söylenebilir.

\section{Kaynakça}

Akgün S, Bakar C, Kut A, Tulgar Kınık S. (2006)Başkent Üniversitesi Hastanesi Pediatri Poliklinikleri'ne başvuran beş yaş altı çocuklarda obezite görülme sıklığı ve etkileyen faktörler. STED, 15; 4: 60-66.

Baysal, A. , (1999),“Beslenme” 4. Baskı, Ankara, H. Ü. Yayınları. 
Boreham, C., Robson, PJ., Gallagher, AM., Cran, GW., Savage, JM., Murray, LJ. (2004). Tracking of physical activity, fitness, body composition and diet from adolescence to young adulthood. The Young Heart Project, Northern Ireland. Int J Behav Nutr Phys Activ, 1,14.

Chen, T.J., Chen, T. J., Modin, B., Ji, C. Y. ve Hjern, A. (2011). Regional, socioeconomic and urban-rural disparities in child and adolescent obesity in China: a multilevel analysis. Acta Paediatrica, 100(12)

Consultation, W. H. O. (2000). Obesity: preventing and managing the global epidemic. World Health Organization Technical Report Series, 894

Davison, K. K., Birch, L. L. (2001). Childhood overweight: A contextual model and recommendations for future research. Obes Rev, 2(3)

Drewnowski, A. ve Specter, S. E. (2004). Poverty and obesity: the role of energy density and energy costs. The American Journal of Clinical Nutrition, 79(1), 616.

Glasper, A. (2010). The fat of the land: obesity prevention over obesity treatment. British Journal of Nursing, 19(4), 212.

Gordon-Larsen, P., McMurray, R. G. ve Popkin, B. M. (2000). Determinants of adolescent physical activity and inactivity patterns. Pediatrics, 105(6), e83- e83.

Heyward, V.H., ve Stolarczyk, L.M. (1996) Applied Body Composition Assessment. Champaign, IL; Human Kinetics, USA.

Lazzer, S., Meyer, M., Derumeaux, H., Boirie, Y., Vermorel, M. (2005). Longitudinal changes in body composition and basal metabolic rate in institutionalized or domiciled obese adolescents.

Lohman, T. G.,Roche, A. F., \&Martorell, R. (1988). Anthropometric standardization reference manual. Human kineticsbooks

Murasko, J.E. (2011). Trends in the associations between family income, height and body mass index in US children and adolescents: Annals of Human Biology, 38 , 290 - 306. doi:10.3109/03014460.2010.537698

Müller, W. (2009). Towards research based approaches for solving body composition problems in sports: ski jumping as a heuristic example. Brit J Sport Med, 43,1013-19.

Özdemir O, Erçevik E, Çalışkan D. (2005)Farklı sosyoekonomik düzeye sahip iki ilköğretim okulunda öğrencilerin büyümelerinin değerlendirilmesi, Ankara Üniversitesi Tıp Fakültesi Mecmuası; 58: 23-90. 
Öztürk, M. (2005) Üniversitede Eğitim Öğretim Gören Öğrencilerde Uluslararası Fiziksel Aktivite Anketinin Geçerliliği ve Güvenirliği ve Fiziksel Aktivite Düzeylerinin Belirlenmesi, Yüksel Lisans Tezi, Hacettepe Üniversitesi, Ankara.

Patrick, H., Nicklas, T. A. (2005). A review of family and social determinants of children's eating patterns and diet quality. Journal of the American College of Nutrition, 24(2).

Semra İ. (2006) Obez Bireylerde Beslenme, Fiziksel Aktivite ve Sosyal Özelliklerin Değerlendirilmesi Y.Lisans Tezi, İstanbul Üniversitesi, İstanbul.

Süzek, H., Arı, Z., Uyanık, B.A. (2005). Muğla'da yaşayan 6-15 yaş okul çocuklarında kilo fazlalığı ve obezite prevalansı. Turkish Journal of Biochemistry, 30: 290295.

Toyran M. Televizyon izleminin ilkokul çocukları üzerindeki bazı fiziksel ve psikososyal etkilerinin incelenmesi. Erişim: (www.cocuk.hacettepe.edu.tr/uzm_2000/Dr_Muge_Toyran.rtf) 17.05.2018.

Tüzün, M. (1999). Obezite ve tedavisi. İstanbul, Mart Matbaacılık.

Uskun E, Öztürk M, Kişioğlu AN, Kırbıyık S, Demirel R. (2005), Illköğretim Öğrencilerinde obezite gelişimini etkileyen risk faktörleri, SDÜ Tıp Fak. Derg; 12(2): 19-25. 